\title{
In vitro behaviour of endothelial cells on a titanium surface Ana Cristina Breithaupt-Faloppa ${ }^{1}$, Wothan Tavares de Lima1, Ricardo Martins Oliveira-Filho ${ }^{1}$ and Johannes Kleinheinz ${ }^{* 2}$
}

\author{
Address: ${ }^{1}$ Department of Pharmacology, Institute of Biomedical Sciences, University of Sao Paulo, Brazil and ${ }^{2}$ Department for Cranio-Maxillofacial \\ Surgery, University Hospital Muenster, Germany \\ Email: Ana Cristina Breithaupt-Faloppa - a.breithaupt@yahoo.com; Wothan Tavares de Lima - wtdelima@icb.usp.br; Ricardo Martins Oliveira- \\ Filho - rmoliveiro@icb.usp.br; Johannes Kleinheinz* - Johannes.Kleinheinz@ukmuenster.de \\ * Corresponding author
}

Published: 23 July 2008

Head \& Face Medicine 2008, 4:14 doi:10.1186/1746-160X-4-14

This article is available from: http://www.head-face-med.com/content/4/1/14

(C) 2008 Breithaupt-Faloppa et al; licensee BioMed Central Ltd.

This is an Open Access article distributed under the terms of the Creative Commons Attribution License (http://creativecommons.org/licenses/by/2.0), which permits unrestricted use, distribution, and reproduction in any medium, provided the original work is properly cited.
Received: 10 March 2008

Accepted: 23 July 2008

\begin{abstract}
Background: Endothelial cells play an important role in the delivery of cells to the inflammation site, chemotaxis, cell adhesion and extravasation. Implantation of a foreign material into the human body determines inflammatory and repair reactions, involving different cell types with a plethora of released chemical mediators. The evaluation of the interaction of endothelial cells and implanted materials must take into account other parameters in addition to the analysis of maintenance of cell viability.
\end{abstract}

Methods: In the present investigation, we examined the behavior of human umbilical vein endothelial cells (HUVECs) harvested on titanium ( $\mathrm{Ti}$ ), using histological and immunohistochemical methods. The cells, after two passages, were seeded in a standard density on commercially plateshaped titanium pieces, and maintained for I, 7 or 14 days.

Results: After I4 days, we could observe a confluent monolayer of endothelial cells (ECs) on the titanium surface. Upon one-day $\mathrm{Ti} /$ cell contact the expression of fibronectin was predominantly cytoplasmatic and stronger than on the control surface. It was observed strong and uniform cell expression along the time of $\alpha 5 \beta$ I integrin on the cells in contact with titanium.

Conclusion: The attachment of ECs on titanium was found to be related to cellular-derived fibronectin and the binding to its specific receptor, the $\alpha 5 \beta$ I integrin. It was observed that titanium effectively serves as a suitable substrate for endothelial cell attachment, growth and proliferation. However, upon a 7-day contact with $\mathrm{Ti}$, the Weibel-Palade bodies appeared to be not fully processed and exhibited an anomalous morphology, with corresponding alterations of PECAM-I localization.

\section{Background}

Since the discovery of endothelial-derived relaxing factor (EDRF) by Furchgott \& Zawadzki [1], in 1980, endothelial cells (ECs) have been recognized to be involved in vascular homeostasis, angiogenesis and repair of injured tissues. ECs play an important role in the trafficking of cells from bloodstream towards an inflammatory site, chemotaxis, cell adhesion and extravasation [2]. Factors released by ECs mediate the control of vascular tonus, thrombogenesis and fibrinolysis, and platelet activities [3]. Besides, by interacting with cytokines and leukocytes, ECs orchestrate the inflammatory process [4], a fact involved with 
the complex phenomena observed at the host implant interface. ECs produce and store the haemosthatic protein von Willebrand factor (vWf) into granules named Weibel Palade bodies (WPBs), that are secretory organelles. They thus provide a readily releasable pool of extracellular VWF as well as placing P-selectin on the plasma membrane whereby it can recruit leukocytes and thus play a role in the initiation of inflammation [5].

Implantation of a foreign material into the intimity of human tissues triggers a typical inflammatory response followed by tissue repair. After implanted, the material will determine the clinical outcome and will have an influence on the implantation bed, triggering cellular and non-cellular responses [6]. Metals and alloys are the most common materials used as surgical implants in order to replace mineralised structures $[7,8]$. In particular, titanium alloys show properties which render them suitable substrates for surgical implant $[6,8]$. Moreover, the high degree of biocompatibility of titanium and its alloys is intimately related to the passively formed oxide film on the metallic surface $[9,10]$.

Noteworthy, the evaluation of the interaction of cells and implanted materials must take into account other parameters in addition to the analysis of maintenance of cell viability. Indeed, the interaction of implants with host cells, and in particular with endothelial cells, might cause activation of adhesion molecules culminating with cytokine generation [2]. In fact, the degree of expression of adhesion molecules on the surface of human ECs depends on the response of the cells against the implanted material [11].

PECAM-1 is a cell-cell junction molecule that establishes homophilic binding between neighboring ECs [12]. PECAM-1 interacts with the underlying cytoskeleton and regulates F-actin assembly at the cell periphery in association with changes in cell shape and spreading [13]. The mechanism of endothelial cell adhesion to substrates involves integrins expression, thence connecting extracellular matrix (ECM) with the cytoskeleton $[14,15]$. Integrins are also considered to be the main receptors of ECM proteins, such as fibronectin, laminin, collagens, and vitronectin. Altogether, these proteins constitute the main mediators of cell-ECM adhesion [14].

There is evidence that upon binding to an ECM protein (e.g. fibronectin), a number of integrins mediate cellular signaling and functions. It was shown that $\alpha 5 \beta 1$ integrin, a receptor for both fibronectin (FN) and vitronectin (VN), and $\alpha v \beta 3$ integrin, a $\mathrm{VN}$ receptor, both play a role in angiogenesis [16]. Therefore, the success of vasculogenesis and angiogenesis depends on FN $[17,18]$ and its main receptor, the $\alpha 5 \beta 1$ integrin [19]. Upon wound repair, ang- iogenetic mechanisms are called into play leading to generation of new capillary blood vessels [20]. Accordingly, angiogenesis is of pivotal importance during the initial healing process, and thus the characterization of the cellular responses involved in angiogenesis and bone formation adjacent to the implants is critical to understanding and promoting implant biocompatibility and improving stable fixation of implants [21].

Tissue repair around an implanted piece of Ti depends crucially on osseous integration and angiogenesis. Though a huge deal of information exist about bone modifications in this situation, the interaction of this metal with endothelial cells is not completely understood. Being so, in this study we investigated the behavior of ECs in culture on Ti plates and assessed the protein expression and cell adhesion, in an attempt to better understand the reasons why Ti-made implant materials achieve successful clinical application.

\section{Materials and methods}

The experimental design was approved by the Ethics Committee, Faculty of Medicine, University of Münster. The material analyzed in this study was commercially available, plate-shaped pieces of pure titanium (Ti). As control surfaces, we used round plastic coverslips (Thermanox ${ }^{\circledR}$, Nunc, USA) coated with gelatin (Sigma, USA).

\section{Antibodies}

All antibodies were used as purified IgGs. Monoclonal antibodies: anti-human CD-31 (PECAM-1), anti-human vinculin (Sigma, USA); anti-human fibronectin receptor (Takara Biomedicals, Japan); anti-human vitronectin, anti-human vitronectin receptor and anti-human VE-cadherin (Chemicon International, USA); anti-human $\alpha$ smooth muscle actin (ICN Biomedicals, USA). Polyclonal antibodies: anti-human von Willebrand factor (vWf)/factor VIII (ICN Biomedicals, USA) and anti-fibronectin (Biotrend, Germany). Second antibodies: alexa fluor 488 goat anti-mouse, and anti-rabbit.

\section{Cultures of human umbilical vein endothelial cells (HUVECs)}

The endothelial cells were isolated from umbilical cord veins essentially as described by Marin et al. [22], according to the method of Jaffe et al. [23]. Cells were pooled and established as primary cultures seeded on $0,5 \%$ gelatin-coated (gelatin 2\% solution) tissue culture dishes in medium 199 enriched with 20\% heat-inactivated fetal bovine serum, $5 \mu \mathrm{g} / \mathrm{ml}$ amphotericin $\mathrm{B}, 200 \mathrm{U} / \mathrm{ml}$ penicillin, $200 \mu \mathrm{g} / \mathrm{ml}$ streptomycin, $1 \%$ endothelial cell growth supplement, and $0,1 \%$ heparin. Cultures were carried out at $37^{\circ} \mathrm{C}$ in a humidified atmosphere with $5 \% \mathrm{CO}_{2}$; the culture medium was changed every other day. The cultures were serially passaged by incubating confluent cells 
in $0.05 \%$ trypsin/0.02\% EDTA solution and replating them at a 1:2 ratio. Second passage cells were taken for the experiments after being identified as endothelial cells by staining with a panel of endothelial-specific antibodies (anti-vWF, anti-CD-31 [PECAM-1]) and by a negative staining to anti- $\alpha$-smooth muscle actin.

\section{Contact assays}

Detachment of cells was performed by trypsinisation during $1 \mathrm{~min}$; the reaction was stopped by dilution with enriched medium and the resulting suspensions were centrifuged $(1,200 \mathrm{rpm}$ for $3 \mathrm{~min})$. The pellet was resuspended in growth medium. Cell numbers were determined with a cell counter. Titanium plates $\left(1 \mathrm{~cm}^{2}\right)$ were placed onto the bottoms of 24-well plates, and the cells were seeded in every well at a density of $8 \times 10^{4}$ cells/ $\mathrm{cm}^{2}$. As control surfaces, we used round pieces (plastic coverslips) with the same dimensions, coated with gelatin and seeded with the same concentration of cells. The experiments were carried out during 1,7 or 14 days and the media were changed every other day.

\section{Immunohistochemistry}

At the end of every culture period, both cell substrates were processed with a fluorescent staining method and studied with a confocal microscope. For this purpose, the substrates inside the wells were rinsed with PBS and fixed in methanol for 20 minutes at $-4^{\circ} \mathrm{C}$. Non-specific sites were then blocked by incubation during 15 minutes at room temperature with Tris-buffered saline/Tween $20^{\circ}$ (TBST) containing $0.5 \%$ bovine serum albumin. Afterwards, the substrates were incubated with the primary antibodies during $1 \mathrm{~h}$ at $37^{\circ} \mathrm{C}$, rinsed three times with TBST and then incubated with the correspondent alexa fluor 488 second antibody for $1 \mathrm{~h}$ at $37^{\circ} \mathrm{C}$. Negative controls were prepared using incubations with primary antibodies-free saline. Images of the stained probes were captured using a confocal microscope (Zeiss Axiovert).

\section{Scanning electron microscopy}

The titanium plates were fixed with $2.5 \%$ glutaraldehyde and then dehydrated using a graded ethanol series. The process was completed by critical point drying using $\mathrm{CO}_{2}$ and a thin layer of gold was sputter-coated onto the plates prior to examination. The images of the surfaces were captured using a Philips PSEM500 $\times$ microscope.

\section{Cell countings}

After the corresponding culture periods, titanium and control pieces were rinsed with PBS to eliminate unattached cells. The adherent cells were removed by incubation with trypsin/EDTA for 2 minutes at $37^{\circ} \mathrm{C}$. Trypsin action was stopped by dilution with complete growth medium at room temperature and $100 \mu \mathrm{l}$-samples of the resulting cell suspensions were counted using a cell coun- ter (Casy ${ }^{\circledR} 1$, Schärfe System, Germany). Results were expressed as the number of adherent cells per sample of titanium or control and were analyzed by one-way analysis of variance and the Tukey-Kramer multiple comparisons test. A 2.01 version GraphPad InStat ${ }^{\mathrm{TM}}$ software was used for this purpose. When appropriate, the Student's $t$ test was also used.

\section{Results}

\section{Material characterization}

Images of titanium plates showed the surface topography and revealed the presence of regular parallel grooves (Figure 1).

\section{Cell morphology}

The morphological observations indicated that the cells seeded on titanium seem to conform to the material surface and to be flat, elongated and oriented along the titanium grooves (Figure 2A). After 7 days we could observe the presence of increased number of cells; after 14 days there was a confluent and dense cell layer (Figure 2B). Cells over the control surface maintained their morphological patterns without any significant volume variation or other modifications.

\section{Titanium assays and immunohistochemistry}

HUVECs adhered to the surface, spread and proliferated and within 24 hours started forming a subconfluent monolayer. On titanium and on control surfaces it could be noticed that the cells proliferated and reached confluence, throughout the experimental period.

Stainings with antibodies anti- PECAM-1 and anti-vWf were performed to confirm the conservation of the

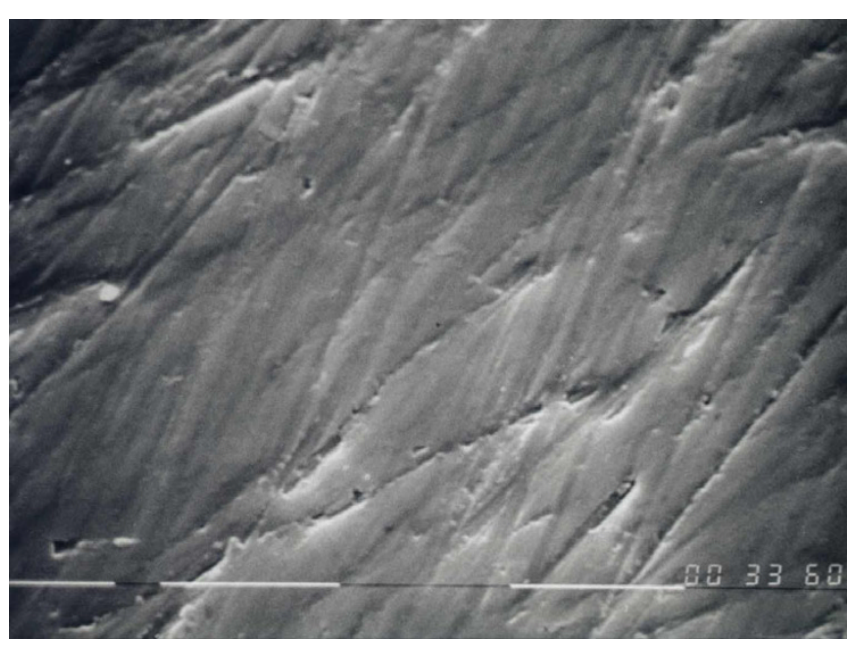

Figure I

Scanning electron microscopy aspect of titanium plate without cells $(2500 \times)$. 

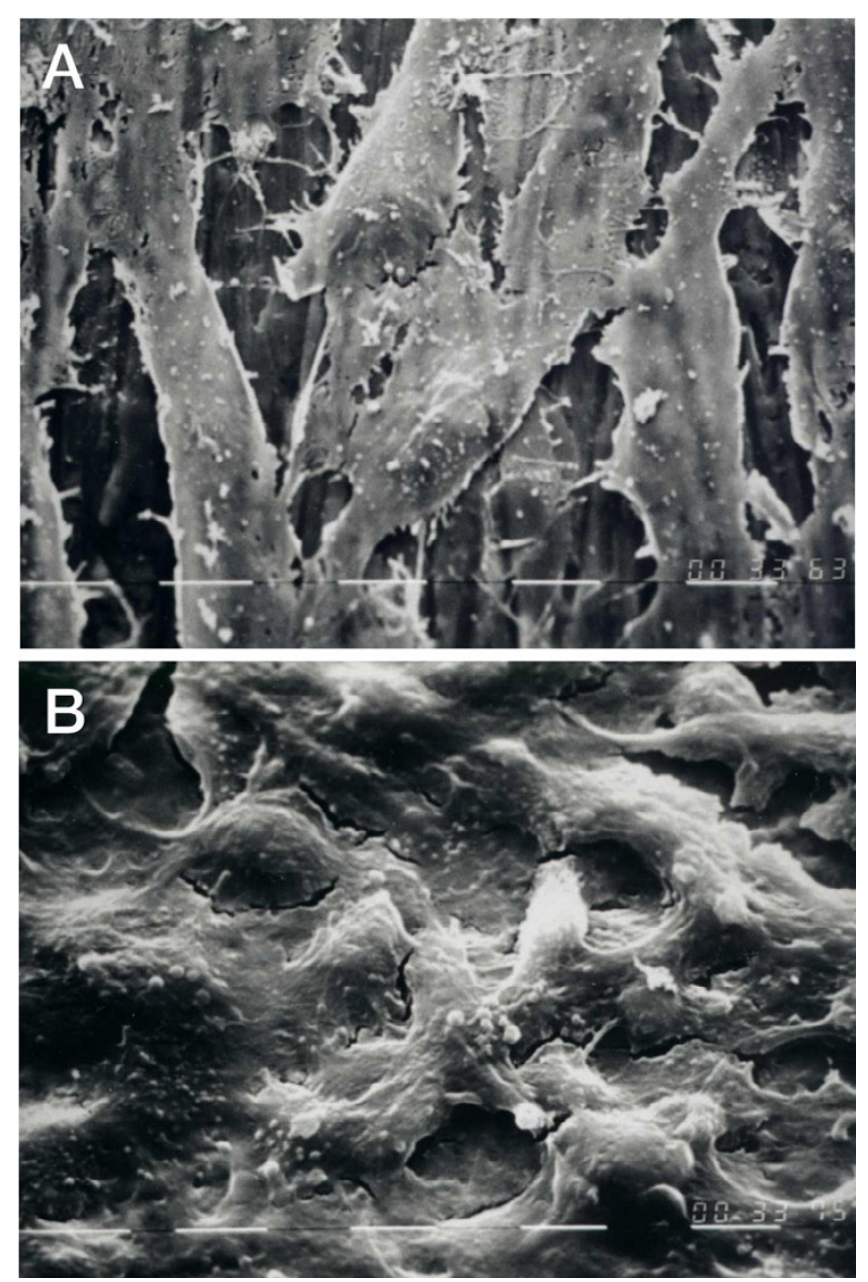

Figure 2

Scanning electron microscopy image of endothelial cells attached to the titanium plate after I day of culture (A) and after I 4 days (B) ( $1250 x$ ).

endothelial characteristics. There was a mild up to strong expression of PECAM-1 by the cells and no expression was evidenced on the cellular processes after 7 days (Figures 3A, B and 3C). Conversely, on the control surfaces the CD-31 expression did not vary during the studied periods (Figures 3D, E and 3F). Cells tested for vWf showed the presence of this factor on titanium and on control surfaces, but on titanium after 7 and 14 days we could not observe well-defined granules in the cells and after 7 days they are distributed on the perinuclear region (Figure $4 \mathrm{~B}$ and 4C). Conversely, on control surfaces the cells presented well-defined vWf granules uniformly distributed in the cells in all studied periods (Figures 4D, E and 4F).

The cells were also studied for the presence of extracellular matrix proteins, fibronectin and vitronectin. The results on both surfaces showed a strong positive reaction for fibronectin with a progressively intensity increase. Upon one-day $\mathrm{Ti} /$ cell contact the expression of fibronectin was predominantly cytoplasmatic and stronger than on the control surface (Figure 5A and 5D). After 7 and 14 days we observed that fibronectin was predominantly extracellular on both surfaces (Figures 5B, C, E and 5F). In contrast, no positive responses were obtained with the specific anti-vitronectin antibody.

Assays for VE-cadherin expression resulted negative, both on control and titanium surfaces for any experimental period studied.

The assays for integrins $\alpha 5 \beta 1$ (Figure 6) and $\alpha(\mathrm{v}) \beta 3$ (Figure 7 ) revealed strong and uniform cell expression along the time, with a stronger reaction for $\alpha 5 \beta 1$ on the cells in contact with titanium or control surfaces.

Similar testings were done for vinculin; the staining was positive and did not significantly vary along the time. The subcellular distribution of this protein, along the Ti/cell contact time, was similar to that of the $\alpha 5 \beta 1$ integrin found after 7 days.

\section{Cell countings}

Figure 8 shows the number of cells attached to titanium and control surfaces after the different growing periods ( 1 , 7 or 14 days). Overall, there was an increasing number of cells adhered to the substrates along the time, without significant difference between titanium and control surface.

\section{Discussion}

Besides requiring invasion by endothelial cells (ECs), angiogenesis depends upon localized proteolytic modifications of the extracellular matrix (ECM) and/or a substrate to which ECs can adhere, migrate upon, proliferate within, and eventually differentiate into a mature EC phenotype. The physical characteristics as well as the composition of the material must be suitable for cell adherence, because focal adhesions can only be formed and maintained when the material sustains cell adhesion. The cellular response to a foreign material is dictated largely by the surface properties of the material to which the cells contact. A better understanding of the role of occurring matrix in the various steps of angiogenesis would conceivably contribute to the intelligent design of tissue-engineered constructs where angiogenesis is critical for tissue repair and restoration [24].

Results from van Kooten et al. [25] showed that HUVECs adhere to metal surfaces and start forming a subconfluent monolayer within 3 days, and that focal contacts are present after 3 days of adhesion, with the cells still displaying their endothelial phenotype. It has been demonstrated that various specific proteins adsorb onto the 


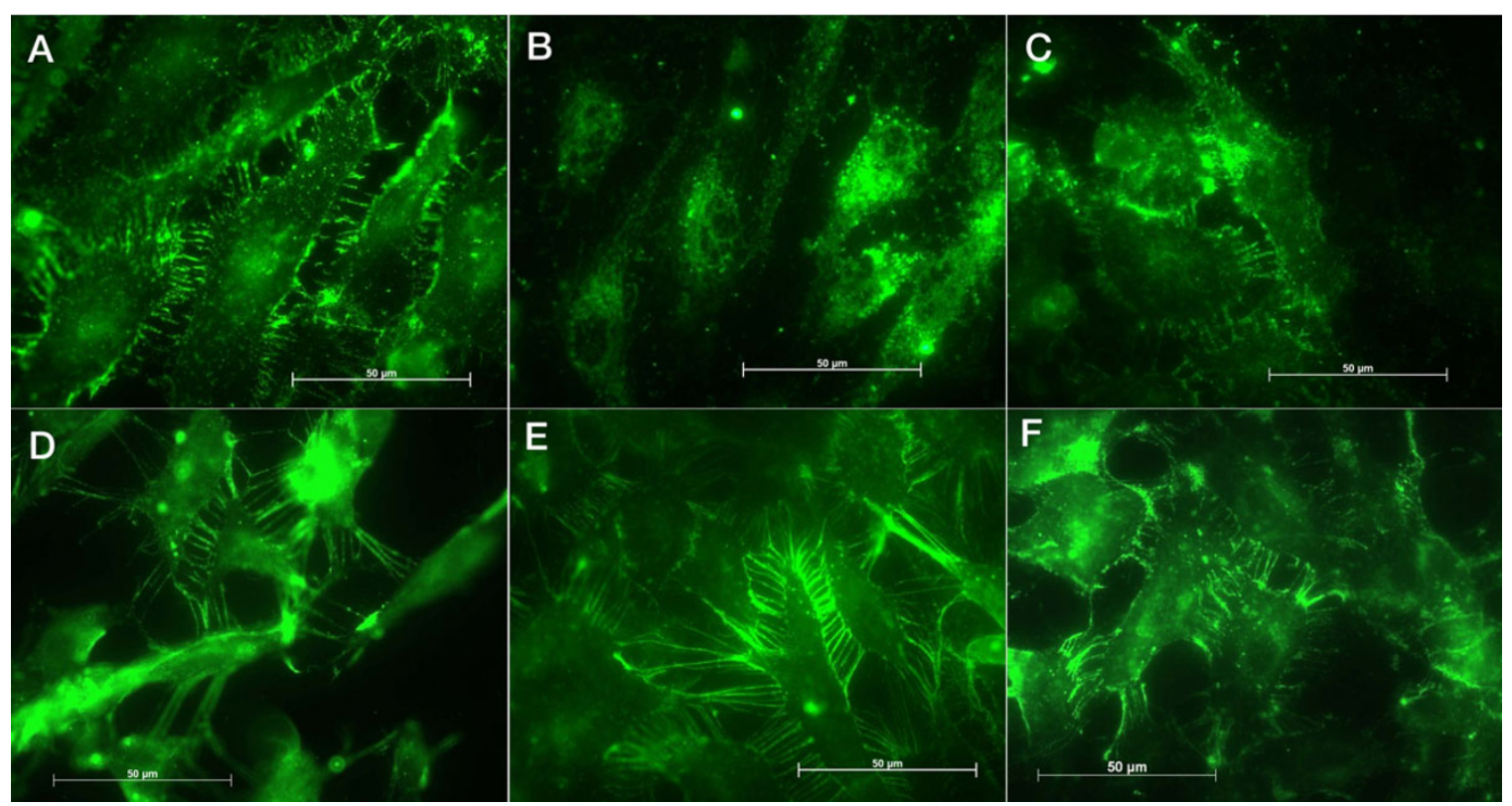

Figure 3

Images of the immunohistochemical assays: PECAM-I on endothelial cells attached to titanium after (A) 24 hours, (B) 7 days and (C) I 4 days, and to control surface after (D) 24 hours, (E) 7 days and (F) I4 days.

scaffolds used for culture from serum-containing medium in vitro, and that cells use specific integrin receptors to bind to these proteins [26].
Tissue repair around an implanted piece of $\mathrm{Ti}$ depends crucially on osseous integration and angiogenesis. Though a huge deal of information exist about bone modifications in this situation, the interaction of endothelial
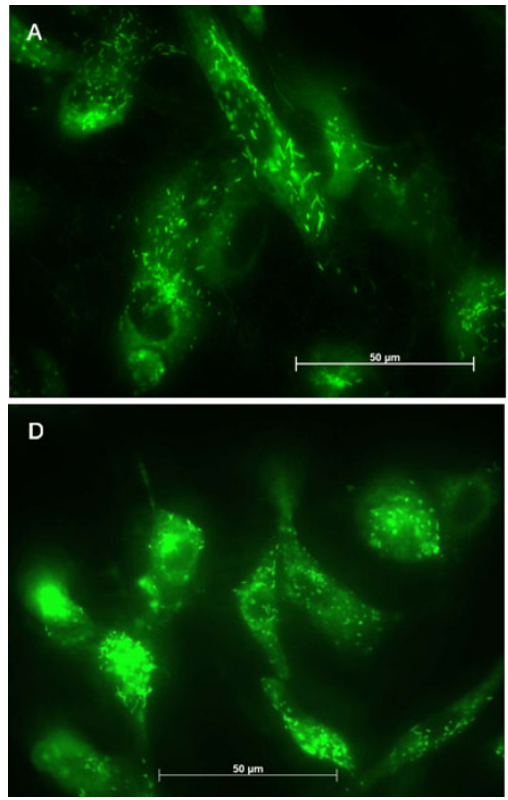
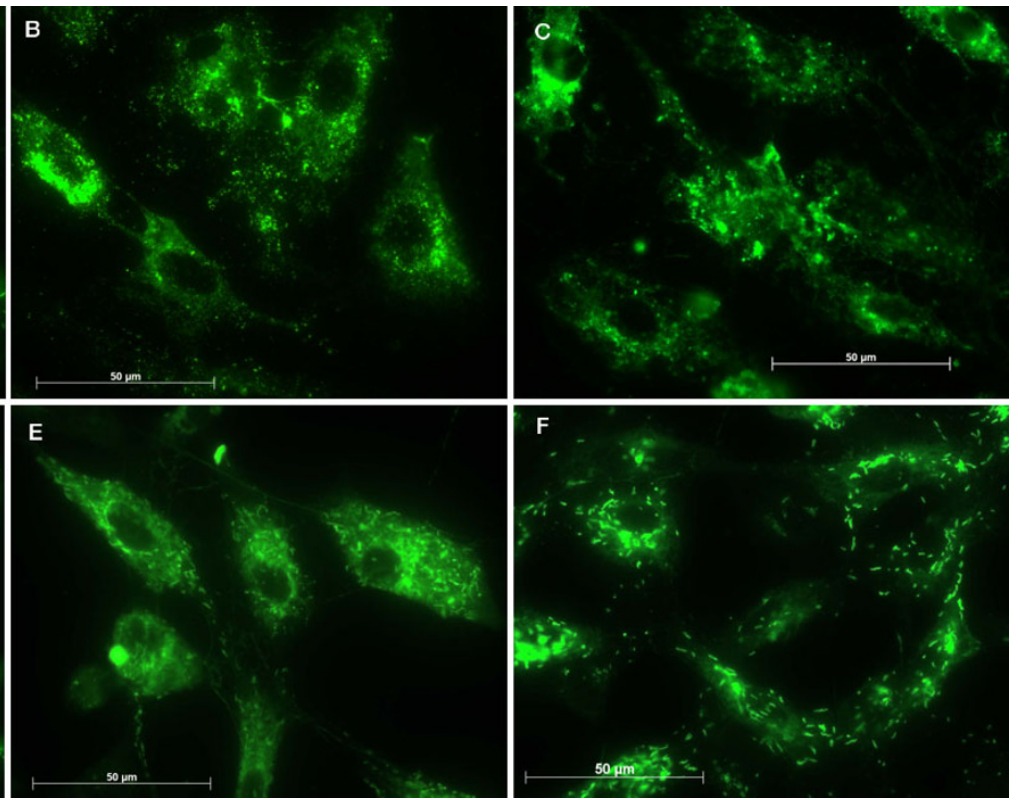

Figure 4

Images of the immunohistochemical assays: von Willebrand factor on endothelial cells attached to titanium after (A) 24 hours, (B) 7 days and (C) I4 days, and to control surface after (D) 24 hours, (E) 7 days and (F) I4 days. 

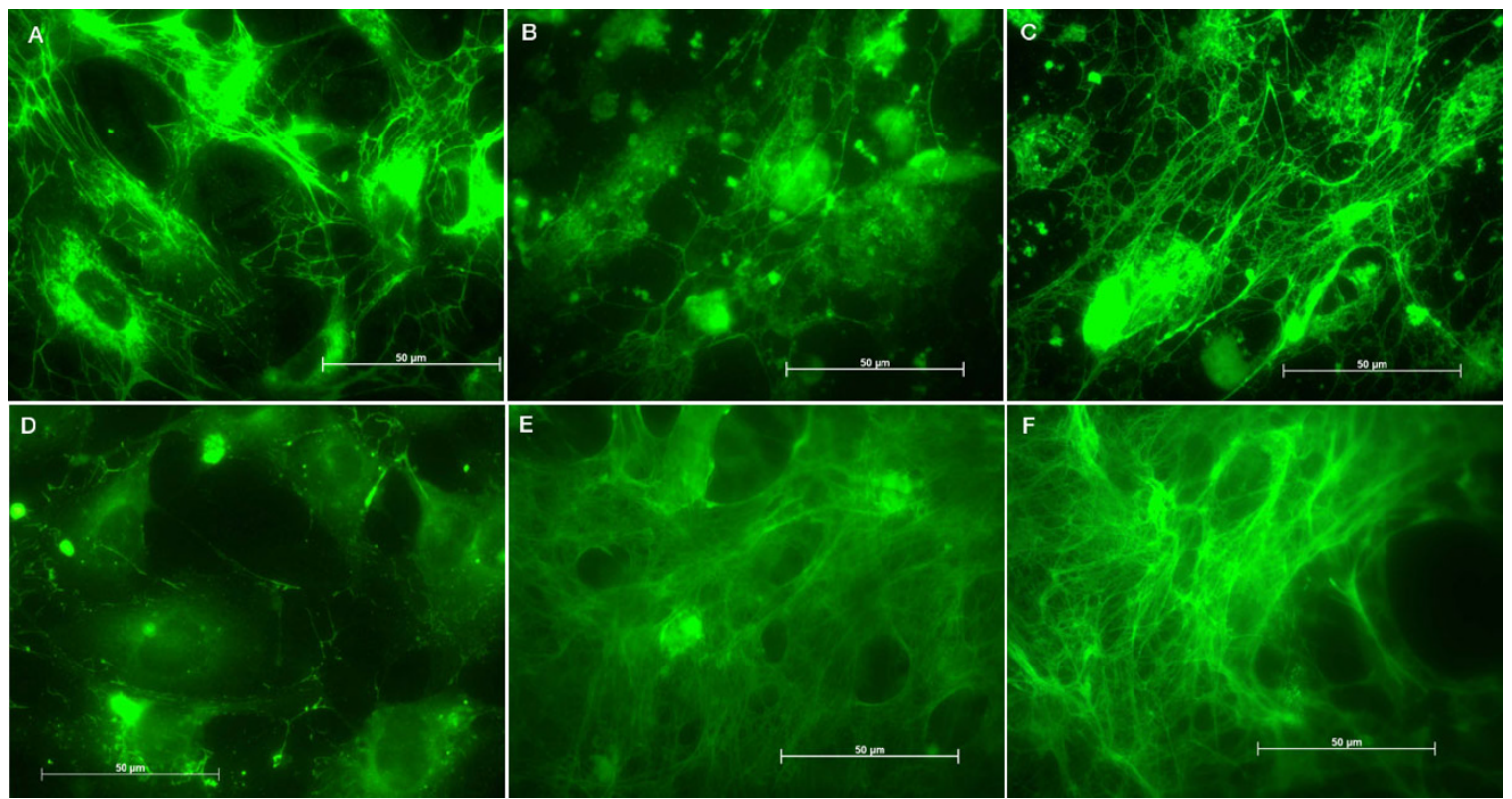

Figure 5

Images of the immunohistochemical assays: fibronectin on endothelial cells on titanium after (A) 24 hours, (B) 7 days and (C) 14 days and on control surface after (D) 24 hours, (E) 7 days and (F) I 4 days.

cells with $\mathrm{Ti}$ is not completely understood. A permanent state of oxidative stress appears to exist in endothelial cells grown in direct contact with $\mathrm{Ti}$ surfaces [27]. These authors showed that HUVECs adhere to Ti in vitro and a complete coverage of an EC layer was obtained without any coating or surface treatment.
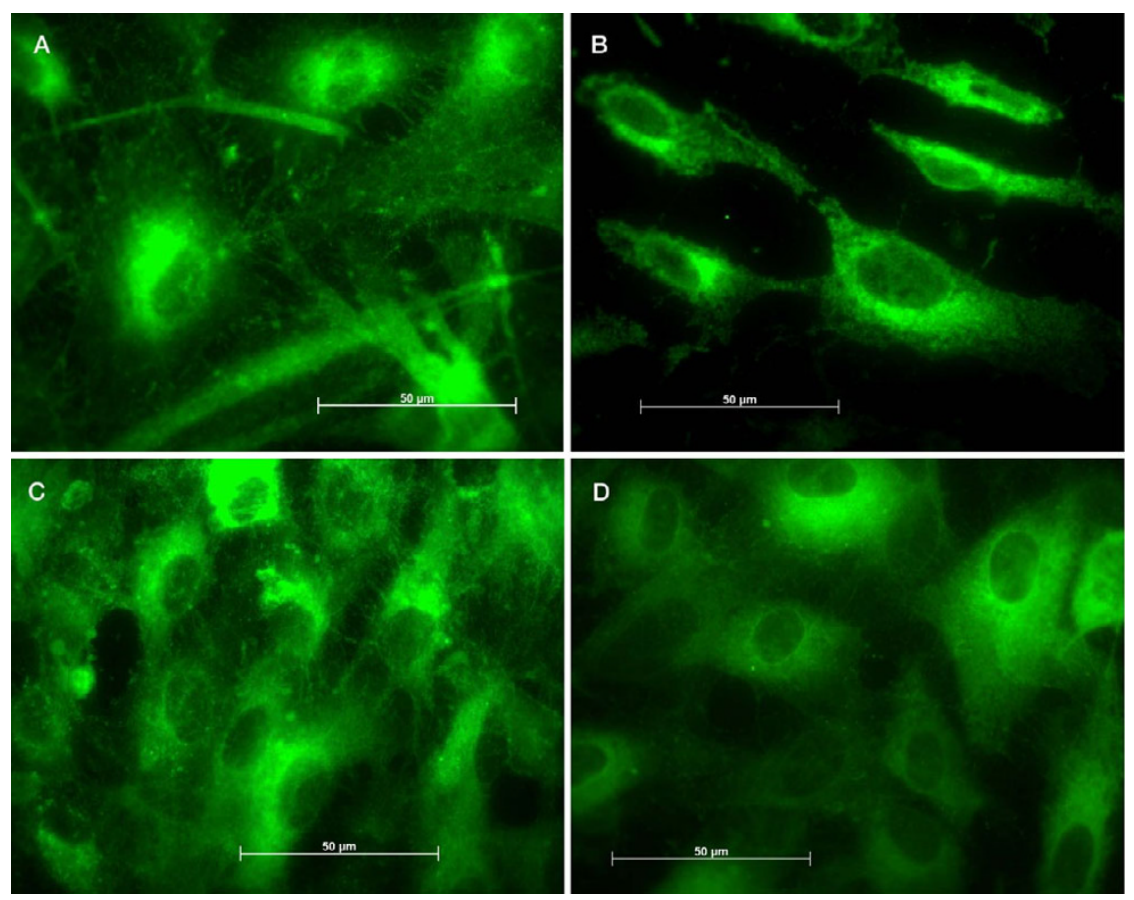

Figure 6

Images of the immunohistochemical assays: $\alpha 5 \beta$ I integrin expression on endothelial cells attached to titanium after (A) 24 hours, (B) 7 days and (C) 14 days and to control surface (D). 

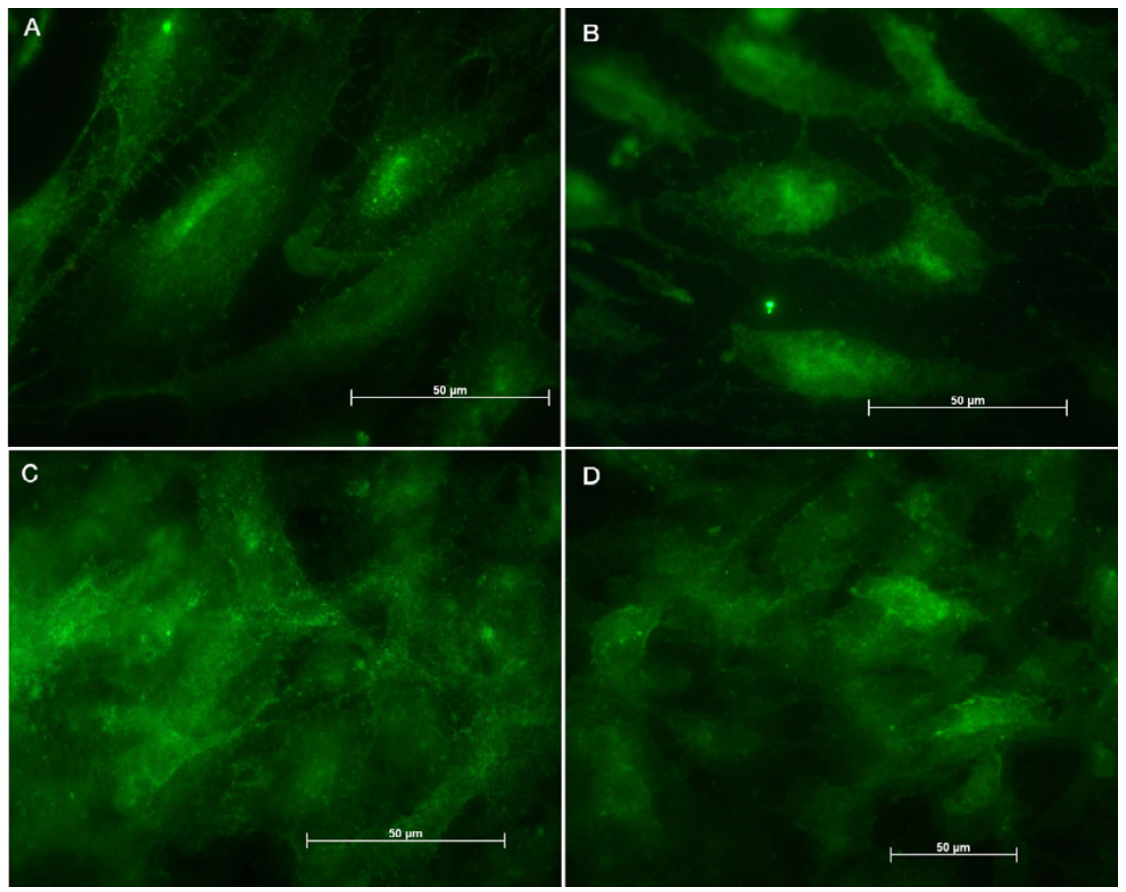

\section{Figure 7}

Images of the immunohistochemical assays: $\alpha(v) \beta 3$ integrin expression on endothelial cells attached to titanium after (A) 24 hours, (B) 7 days and (C) 14 days and to control surface (D).

Cell adhesion to implants in vivo and to culture surfaces in vitro is typically dependent upon surface-adsorbed fibronectin and vitronectin [28]. After 1 day on titanium (see Fig. 5) it could be observed a strong cytoplasmatic pool of fibronectin on ECs and a growing extracellular mesh. Conversely, on control surfaces that fibronectin pool was not observed. After 7 days this protein was found over both surfaces with a more dense mesh on the control surfaces. The cells produced and released fibronectin in

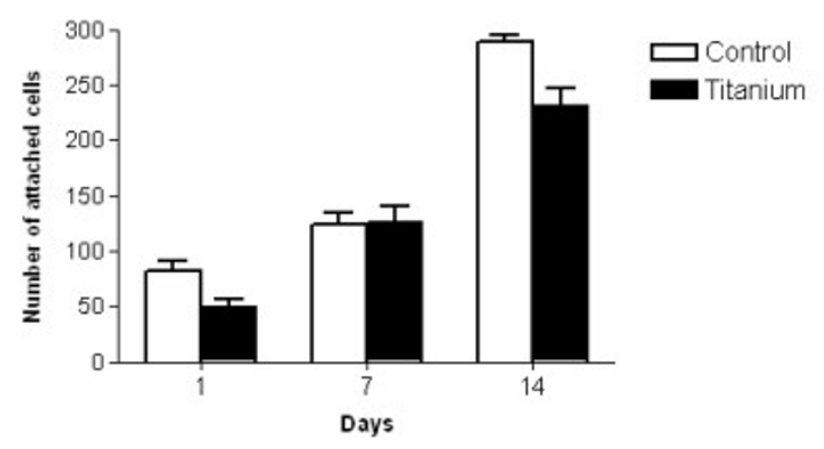

Figure 8

Attachment of HUVECs on titanium and on control surfaces after the studied periods. Values are mean \pm SEM. order to use this protein as a substrate for attachment, with a stronger presence in the cells after 1 day on titanium. On control surfaces the initial attachment was most conceivably based on the gelatin coat. Although it has been stated that over time the adhesion may be progressively more dependent on vitronectin in view of the larger amounts, or the preferential binding to this molecule $[29,30]$, our data do not support this view, since our EC vitronectin stainings failed to demonstrate any positive answer either on titanium or control surfaces. Our findings showed that ECs produced and eliminated endogenous fibronectin, using this protein to attach to the surface through integrins (namely, $\alpha v \beta 1$ and $\alpha v \beta 3$ ) which are expressed when ECs were seeded on titanium. The observed expression of $\alpha v \beta 3$ was weaker in comparison to that of $\alpha 5 \beta 1$ (Figs. 6 and 7).

The EC morphology on titanium plates was not altered. However, WPBs were not well-defined after 7 and 14 days and they were distributed on the perinuclear region. Some authors report that only fully processed, substantially polymerized and functionally mature vWf is stored in the WPBs, together with its propeptide [31]. Interestingly, it is established that HUVECs poses two different populations of WPBs, that are differentiated at cellular level by their distribution, the newly formed ones being immature and located in the perinuclear region [5]. Thus it is conceivable 
to infer that on titanium, after 7 and 14 days, the WPB on HUVECs were immature in nature as judged by their distribution (Fig. 4) whereas the mature granules were secreted. On the other hand, the presence and the distribution of the WPBs on HUVECs on control surfaces were uniform in all studied periods.

Since PECAM-1-mediated pathway could be involved in the observed differences in cell behavior, the expression level of PECAM-1 on titanium was analyzed. CD-31 (PECAM-1) was expressed mildly up to strongly by the cells on Ti, but we could not observe the expressed CD-31 on the cellular processes after 7 days (Fig. 3). Since this was not observed with control surfaces, those cell contact alterations might well be due to an effect of titanium on HUVECs.

Our results did not show the presence of VE-cadherin within junctions in all periods studied neither in contact with titanium nor with the control surface. This could be an evidence of a lack of some stimulus (i) for this molecule to trigger its participation on the junctions.

\section{Conclusion}

In conclusion, our data indicated that the attachment of ECs on titanium could be related to cellular-derived fibronectin and the binding to its specific receptor, the $\alpha 5 \beta 1$ integrin. It was observed that titanium effectively serves as a suitable substrate for endothelial cell attachment, growth and proliferation in the initial phase. It is suggested to describe this feature of titanium if not angiogenic then at least angio-conductive. However, upon a 7-day contact with Ti the Weibel-Palade bodies were found to be not fully processed and with altered morphology, which corresponding alterations of PECAM-1 localization. In fact that the successful Ti devices implantation coexists with the microscopical subclinical adverse effects is, at the present, unresolved.

\section{Authors' contributions}

ACB-F performed all experiments under the supervision of JK. ACB-F drafted the manuscript and was advised by RMO-F and WTdL. All authors read and approved the final manuscript.

\section{Acknowledgements}

We thank Mrs. Schuette, Mrs. Hartmann and Mr. Huda for their useful and informative technical assistance.

ACBF was recipient of Deutscher Akademischer Austausch Dienst (DAAD)/CAPES fellowship.

\section{References}

I. Furchgott RF, Zawadzki JV: The obligatory role of endothelial cells in the relaxation of arterial smooth muscle by $\mathrm{ACh}$. Nature 1980, 288:373-376.
2. Santos MI, Fuchs S, Gomes ME, Unger RE, Reis RL, Kirkpatrick C): Response of micro- and macrovascular endothelial cells to starch-based fiber meshes for bone tissue engineering. Biomaterials 2007, 28(2):240-248.

3. Davies MG, Hagen PO: The vascular endothelium. A new horizon. Ann Surg 1993, 21 8:593-609.

4. Bruni S, Martinesi M, Stio M, Treves C, Bacci T, Borgioli F: Effects of surface treatment of Ti-6Al-4V titanium alloy on biocompatibility in cultured human umbilical vein endothelial cells. Acta Biomater 2005, I(2):223-34.

5. Harrison-Lavoie KJ, Michaux G, Hewlett L, Kaur J, Hannah MJ, LuiRoberts WWY, Norman KE, Cutler DF: P-selectin and CD63 use different mechanisms for delivery to Weibel-Palade bodies. Traffic 2006, 7(6):647-62.

6. Ramires PA, Giufrida A, Milella E: Three-dimensional reconstruction of confocal laser microscopy images to study the behaviour of osteoblastic cells grown on biomaterials. Biomaterials 2002, 23:397-406.

7. Williams JM, Buchanan RA: Ion implantation of surgical Ti-6Al4V alloy. Mater Sci Eng 1985, 69:237-46.

8. Long $M$, Rack HJ: Titanium alloys in total joint replacement-a materials science perspective. Biomaterials 1998, I9:162 |-39.

9. Lausmaa J, Mattson L, Rolander U, Kasemo B: Chemical composition and morphology of titanium surface oxides. Mater Res Soc Symp Proc 1986, 55:351-9.

10. Ito M, Azuma Y, Ohta T, Komorita K: Effects of ultrasound and 1,25-dihydroxyvitamin $D_{3}$ on growth factor secretion in cocultures of osteoblasts and endothelial cells. Ultrasound Med Biol 2000, 26:161-6.

II. Pu FR, Williams RL, Markkula TK, Hunt JA: Effects of plasma treated PET and PTFE on expression of adhesion molecules by human endothelial cells in vitro. Biomaterials 2002, 23:24II-28.

12. Albelda SM, Buck CA: Integrins and other cell adhesion molecules. FASEB J 1990, 4:2868-2880.

13. Newman PJ, Newman DK: Signal transduction pathways mediated by PECAM-I: new roles for an old molecule in platelet and vascular cell biology. Arterioscler Thromb Vasc Biol 2003, 23:953-64.

14. Alexander JS, Elrod JW: Extracellular matrix, junctional integrity and matrix metalloproteinase interactions in endothelial permeability regulation. J Anat 2002, 200:56I-74.

15. Breithaupt-Faloppa AC, Kleinheinz J, Crivello $O$ Jr: Endothelial cell reaction on a biological material. J Biomed Mater Res B Appl Biomater 2006, 76(I):49-55.

16. Ruegg C, Mariotti A: Vascular integrins: pleiotropic adhesion and signaling molecules in vascular homeostasis and angiogenesis. Cell Mol Life Sci 2003, 60(6): I I35-57.

17. George EL, Georges-Labouesse EN, Patel-King RS, Rayburn H, Hynes $\mathrm{RO}$ : Defects in mesoderm, neural tube and vascular development in mouse embryos lacking fibronectin. Development 1993, I 19:1079-1091.

18. George EL, Baldwin HS, Hynes RO: Fibronectins are essential for heart and blood vessel morphogenesis but are dispensable for initial specification of precursor cells. Blood 1997, 90:3073-308I.

19. Francis SE, Goh KL, Hodivala-Dilke K, Bader BL, Stark M, Davidson $D$, Hynes RO: Central roles of alpha5betal integrin and fibronectin in vascular development in mouse embryos and embryoid bodies. Arterioscler Thromb Vasc Biol 2002, 22:927-933.

20. Folkman J, Shing Y: Angiogenesis. J Biol Chem 1992, 267:1093 I-34.

21. Smith RA, Mosesson MW, Daniels AU, Gartner TK: Adhesion of microvascular endothelial cells to metallic implant surfaces. J Mater Sci: Mater Med 2000, I I:279-285.

22. Marin V, Kaplanski G, Grès S, Farnarier C, Bongrand P: Endothelial cell culture: protocol to obtain and cultivate human umbilical endothelial cells. J Immunol Methods 200I, 254: I83-90.

23. Jaffe EA, Nachmann RL, Becker CG, Minick CR: Culture of human endothelial cells derived from umbilical veins - identification by morphologic and immunologic criteria. J Clin Invest 1973, 52:2745.

24. Dixit P, Hern-Anderson D, Ranieri J, Schmidt CE: Vascular graft endothelization: comparative analysis of canine and human endothelial cell migration on natural biomaterials. J Biomed Mater Res 200I, 56:545-55. 
25. van Kooten TG, Klein CL, Kirkpatrick Cl: Cell-cycle control in cell-biomaterial interactions: expression of p53 and Ki67 in human umbilical vein endothelial cells in direct contact and extract testing of biomaterials. J Biomed Mater Res 2000, 52:199-209.

26. Baccells M, Edelman ER: Effect of pre-absorbed on attachment, proliferation, and function of endothelial cells. J Cell Physiol 2002, 191:|55-61.

27. Tsaryk R, Kalbacova M, Hempel U, Scharnweber D, Unger RE, Dieter $P$, Kirkpatrick C], Peters K: Response of human endothelial cells to oxidative stress on Ti6Al4V alloy. Biomaterials 2007, 28(5):806-13.

28. Grinnell F, Feld MK: Fibronectin adsorption on hydrophilic and hydrophobic surfaces detected by antibody binding and analyzed during cell adhesion in serum-containing medium. J Biol Chem 1982, 257(9):4888-93.

29. Garner B, Hodgson AJ, Wallace GG, Underwood PA: Human endothelial cell attachment to and growth on polypyrroleheparin is vitronectin dependent. J Mater Sci Mater Med 1999, I0(1):19-27.

30. Nikolovski J, Mooney DJ: Smooth muscle cell adhesion to tissue engineering scaffolds. Biomaterials 2000, 21:2025-32.

31. De Wit TR, Van Mourik JA: Biosynthesis, processing and secretion of von Willebrand factor: biological implications. Best Pract Res Clin Haematol 200I, 14(2):24I-55.

Publish with Biomed Central and every scientist can read your work free of charge

"BioMed Central will be the most significant development for disseminating the results of biomedical research in our lifetime. "

Sir Paul Nurse, Cancer Research UK

Your research papers will be:

- available free of charge to the entire biomedical community

- peer reviewed and published immediately upon acceptance

- cited in PubMed and archived on PubMed Central

- yours - you keep the copyright

Submit your manuscript here:

http://www.biomedcentral.com/info/publishing_adv.asp 